\title{
Changes in the methane emissions and hard coal output in the Brzeszcze mine (the Upper Silesian Coal Basin, Poland)
}

\author{
Marcin Dreger \\ University of Silesia in Katowice, Faculty of Natural Sciences, Institute of Earth Sciences; \\ ul. Będzińska 60, 41-200 Sosnowiec, Poland; e-mail: marcin.dreger@interia.pl; ORCID ID: 0000-0002-7250-2523
}

(C) 2020 Author. This is an open access publication, which can be used, distributed and reproduced in any medium according to the Creative Commons CC-BY 4.0 License requiring that the original work has been properly cited.

Received: 12 March 2020; accepted: 27 August 2020; first published online: 31 August 2020

\begin{abstract}
The paper presents the variability of methane emissions in mining excavations in the Brzeszcze mine (Poland) against the background of hard coal output, geological and mining factors. The geological structure of the Upper Silesian Coal Basin (USCB) is very diverse. The Brzeszcze coal deposit is located close to the large and permeable Jawiszowice fault which increases the methane hazard during mining activities performed close to this fault. The overall decrease in hard coal output (1988-2018) has coincided with a rapid increase in methane emissions (1997-2018). Throughout the study period, hard coal output decreased threefold from 3.9 to 1.2 million Mg annually. Coal extraction in high methane content beds (e.g. 510, 405/1, 364, 352) increases the total methane $\left(\mathrm{CH}_{4}\right)$ emission into mining excavations, aggravating the methane hazard due to the high explosiveness of the gas. To protect miners, coal workings need to be continuously ventilated, taking the harmful gas out of the mine (ventilation air methane emission) or methane needs to be captured by underground methane systems (degassing). Every year, over 34 million $\mathrm{m}^{3}$ of $\mathrm{CH}_{4}$ is captured by the drainage systems and over 70 million $\mathrm{m}^{3} \mathrm{CH}_{4}$ (average) is discharged through ventilation shafts into the atmosphere. The presence of the large, permeable regional dislocation, the Jawiszowice fault zone, shaped the methane concentration in the fault vicinity, when the highest methane emissions during coal mining was studied.
\end{abstract}

Keywords: methane emission, the Upper Silesia Coal Basin, hard coal production, ventilation air methane, the Brzeszcze mine

\section{INTRODUCTION}

The Brzeszcze mine is located in the Upper Silesian Coal Basin (Poland) in the Małopolska and Silesia voivodeships (provinces) (Fig. 1). The Upper Silesian Coal Basin (USCB) is the largest coal basin in Poland, and one of the largest in $\mathrm{Eu}$ rope. It covers an area of $5,600 \mathrm{~km}^{2}$ in Poland and $1,900 \mathrm{~km}^{2}$ in the Czech Republic (Kędzior 2009). The USCB sedimentary basin was formed during the Variscan orogeny. At the end of the Permian period, the denudation and weathering processes of uplifted Paleozoic strata began. In the Miocene period, marine transgression took place in the USCB area. The Upper Carboniferous strata was developed in an area with lush plants and trees after the sea retreated. Thick and continuous loam layers were deposited directly onto the Carboniferous strata, preventing methane and other gases from being naturally released directly into the atmosphere. The thickness of the Carboniferous strata exceeds 6,000 m (Bałuk \& Wyrwicki 1972, Kotas 1990). Hard coal production is one of the most strategic branches in the economy 
and power production in Poland. Almost 50\% of the energy produced comes from hard coal power plants. Poland is the biggest hard coal producer in Europe, but Germany is the biggest hard coal consumer for power production $(93 \mathrm{TWh}$ produced from coal). Poland, with $79 \mathrm{TWh}$, is in second place (Euracoal 2019). Coal from USCB is derived from increasingly deeper beds every year, a trait characteristic of underground coal mining. In 2000 , the average depth of extraction was $600 \mathrm{~m}$, ten years later it was $700 \mathrm{~m}$, and the depth is increasing by $8-10 \mathrm{~m}$ every year. In the last year of studies (2018), the average depth was $788 \mathrm{~m}$ (Szlązak et al. 2013, Report 1995-2018). In the Brzeszcze mine, the deepest level of coal production is at $640 \mathrm{~m}$ below the sea level $(900 \mathrm{~m}$ below the ground surface) (Report 1995-2018, Tauron - internal report). Deeper coal production is related to an increasing methane hazard. Deeper developed beds, rich in $\mathrm{CH}_{4}$ (higher methane content) are the prevailing source of increasing total methane emissions in the Brzeszcze mine and in the entire Upper Silesian Coal Basin (e.g. Dreger \& Kędzior 2019). Underground coal mining is characterised by the occurrence of many natural hazards. The most important and dangerous at the same time are rock bursts, tremors, fire hazard, coal dust explosion, water hazard and, as studied in this paper, methane hazards. Unfortunately, in many cases these hazards occur, making the coal production very dangerous (e.g. Trenczek 2016, Szlązak et al. 2020). Methane occurrence in coal bearing formations is connected with organic substance transformation processes (diagenesis phase) into lignite and further, into hard coal (catagenesis phase). During sedimentation and tectonic processes, peat and lignite were covered by younger deposits. Thick overburden, greater depths, pressure and temperature transformed lignite into hard coal.

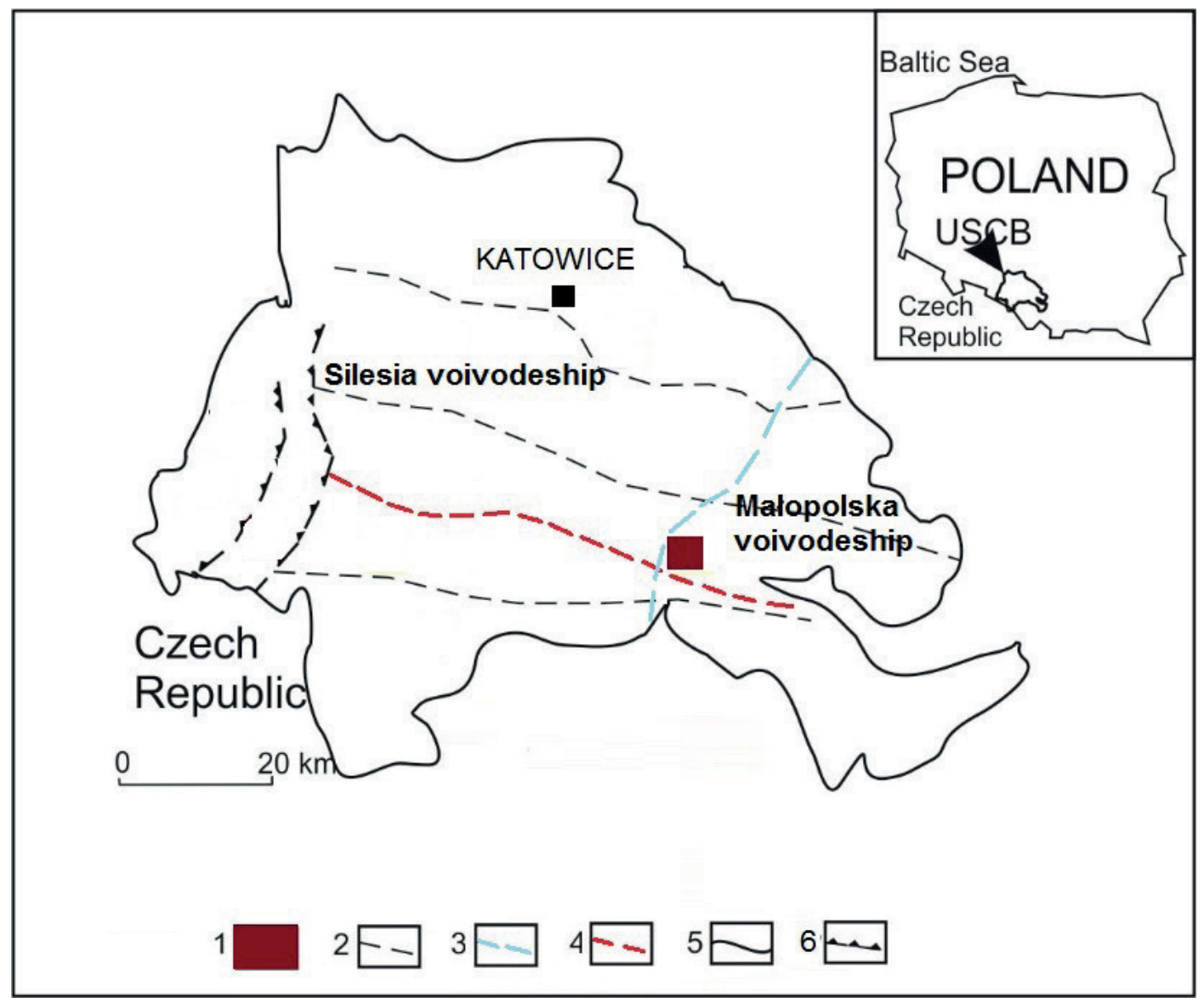

Fig. 1. The Brzeszcze coal mine location: 1 - Brzeszcze mine, 2 - faults, 3 - Silesia and Małopolska boundary line, 4 - the Jawiszowice fault, 5 - the USCB boundary, 6 - overthrusts 
Methane accumulated in coal-bearing series especially due to the sorption properties of microporous coal substances and also due to the impermeable or poorly permeable overburden which prevented the migration of gases to the surface, contributing to the differential saturation of $\mathrm{CH}_{4}$ in coal deposits (e.g. Hunt 1979, Kozłowski \& Grębski 1982, Honysz 2015, Krause 2019).

The hard coal output since the 1990s to the present day has been significantly and constantly decreasing. In the 1990's, coal production exceeded 120 million Mg annually and had more than halved by 2018 to 54 million $\mathrm{Mg}$. In the mid-nineties, 65 coal mines were active in the entire area of the Upper Silesian Coal Basin. Due to coal reserves depletion, financial issues or tough geological and mining conditions many coal mines were closed or merged with neighbouring plants. From the mid-nineties to 2018, the number of working mines dropped to 25 (Dreger \& Kędzior 2019, Kędzior \& Dreger 2019, Report 1995-2018). In the similar period from the mid-nineties to the present day, the methane emissions from all working coal mines in the USCB oscillated between 700 and 900 million $\mathrm{m}^{3}$ of emitted $\mathrm{CH}_{4}$ per year. The highest amounts of methane released into coal workings were recorded in 2017, when 950 million $\mathrm{m}^{3}$ were emitted (Report 1995-2018, Dreger 2019, Dreger \& Kędzior 2019, Kędzior \& Dreger 2019).

The purpose of this paper is to show the causes and effects of changes in methane emissions in the Brzeszcze mine. These changes are shown against the background of coal production, geological and mining factors. The studies of methane release changes were made for the 1997-2018 time period, during which coal production entered coal seams with higher methane content and when a constant decline in hard coal output was observed. As a result, the Brzeszcze mine has been struggling with one of the highest methane emissions in the entire Upper Silesian Coal Basin.

\section{METHODOLOGY}

The paper presents the variabilities of absolute methane emissions, ventilation air methane emissions, outgassing (1997-2018) and hard coal production (1988-2018) in the Brzeszcze mine in the south-eastern part of the USCB. The description of methane emissions and hard coal production was taken from official geological documentation/internal reports prepared specifically for the Tauron Wydobycie - Brzeszcze mine (Tauron - internal report). The data comprise: geological structure of coal deposits, stratigraphy, lithology, tectonics, methane emissions, methane content and overall hard coal output. Supplementary data were used from Annual Report (for the years 1994-2018) on the state of basic natural and technical hazards in the hard coal mining industry (Report 1995-2018) published annually by the Central Mining Institute (Główny Instytut Górnictwa) in Katowice and The Accident Statistics (State Mining Authority 2019) published by the State Mining Authority (Wyższy Urząd Górniczy) in Katowice.

The natural methane concentration in coal (methane content) was measured for the gas conditions assessments required by Geological and Mining Law, 2011 and Regulation of the Ministry of the Environment 2013. The measurements were carried out in mine workings (coal samples collected from 3.5-4.0 m deep wall boreholes) and using deep boreholes drilled from ground surface (a small number). Methane concentration was measured by vacuum degasification and calculated as $\mathrm{m}^{3}$ of $\mathrm{CH}_{4}$ per one $\mathrm{Mg}$ of coal ${ }^{\text {daf }}$ (daf - dry and ash free coal substance).

The balance of the absolute methane emission of the coal mine $Q_{m e}$ is based on the sum of ventilation air emission $\left(Q_{\nu}\right)$ and outgassing $\left(Q_{0}\right)$ :

$Q_{m e}=Q_{v}+Q_{o}$,

where:

$Q_{m e}$ - the absolute/total methane emission $\left[\mathrm{m}^{3} / \mathrm{min}\right.$, million $\mathrm{m}^{3} /$ year],

$Q_{v}$ - the ventilation air methane (VAM) emission $\left[\mathrm{m}^{3} / \mathrm{min}\right.$, million $\mathrm{m}^{3} /$ year],

$Q_{o}$ - the outgassing/methane drainage $\left[\mathrm{m}^{3} / \mathrm{min}\right.$, million $\mathrm{m}^{3} /$ year].

The VAM emission $Q_{v}$ contains the average volume of methane which was released into the ventilation air flowing in mine workings, diluted with mining air and taken out of the mine by underground ventilation shafts. The volume of $\mathrm{CH}_{4}$ in the air flow is measured by methane sensors. The outgassing $Q_{o}$ refers to the average volume of captured methane from the underground methane drainage network, measured by gas/methane detectors in the methane drainage pipelines released from the ventilation area (Koptoń \& Wierzbiński 2014). 
The specific methane emission $\left(Q_{s p}\right)$ refers to volume of emitted methane with every single extracted $\mathrm{Mg}$ of coal, and is given as $\mathrm{m}^{3} / \mathrm{Mg}$ :

$Q_{s p}=\frac{Q_{m e}}{P_{c}}$,

where:

$Q_{s p}$ - specific methane emission $\left[\mathrm{m}^{3} / \mathrm{Mg}\right]$,

$Q_{m e}$ - the absolute/total methane emission $\left[\mathrm{m}^{3} / \mathrm{min}\right.$, million $\mathrm{m}^{3} /$ year],

$P_{c}$ - the hard coal output $[\mathrm{Mg} / \mathrm{day}$, million $\mathrm{Mg} /$ year].

\section{STRATIGRAPHY, LITHOLOGY AND TECTONICS}

The geological structure of the Brzeszcze coal deposit consists of Quaternary, Neogene (overburden) and Carboniferous (coal bearing strata) deposits. Coal beds are found at 40 to $1,150 \mathrm{~m}$ below ground level and coal seam thickness is variable.

\section{Carboniferous}

The Upper Silesian Sandstones Series (USSS) was deposited discordantly upon the Paralic Series and it is the first lithostratigraphic unit of the continental Carboniferous coal bearing strata in the USCB (Jureczka \& Kotas 1995). The coal bearing strata has been prospected to $1,150 \mathrm{~m}$ below ground level, where the bottom of the 510 coal seam occurs. There are 31 documented coal seams in the Brzeszcze coal deposit. For the coal deposits in the Brzeszcze mine, the Doktorowicz-Hrebnicki \& Bocheński division was applied (Doktorowicz-Hrebnicki \& Bocheński 1952):

- Westphalian C - Łaziska layers (coal seams group 200),

- Westphalian B - Orzesze layers (coal seams group 300),

- Westphalian A - Ruda layers (coal seams group 400),

- Namurian B-C - Saddle layers (coal seams group 500),

- Namurian A - Poruba layers (coal seams group 600).

Poruba layers consist of siltstones and mudstones interbedded by fine-grained sandstones and a few thin coal seams. The thickness of the Poruba layers has not yet been established, but the highest thickness found by deep drillings is
$275 \mathrm{~m}$. The most important prospected coal seam, 610 , is not currently exploited.

Saddle layers are the thinnest complex documented in the Brzeszcze coal deposit. The thickness varies from a few to $20 \mathrm{~m}$. Layers developed as concise fine and medium grained sandstone, with the currently exploited coal seam 510 . The bottom of the 510 coal seam forms the bottom of the Saddle layers.

Ruda layers are represented by a siltstone-sandstone complex with a thickness of $120 \mathrm{~m}$. Middle and fine-grained sandstones were deposited in lower parts of the complex, beneath the 407 coal seam. There are six documented seams 401 is now operated, 405/1, 405/2 and 407 were exploited in the past, but 404 and 416 have never been used for coal extraction.

Orzesze layers are found over the entire Brzeszcze coal deposit with their thickness increasing from the east $(375 \mathrm{~m})$ to the west $(545 \mathrm{~m})$, with average thickness of $500 \mathrm{~m}$ in the central part of the deposit. The Orzesze layers were developed as siltstones, mudstones and sandstones with numerous coal seams. There are 19 documented coal seams, with 15 operating in the past, but now only coal bed 352 is being exploited.

Laziska layers are built mainly of fine, medium and coarse-grained sandstones, with minor occurrences of siltstones. The thickness of these layers is very diverse, but the largest thickness over $275 \mathrm{~m}$ - was found in the northern part of the deposit. Of coal seams of the 200 group, only coal seam 215 was mined.

\section{Neogene (Miocene)}

Neogene (Miocene) deposits are represented by loams, shale loams with sand inserts. The thickness of Miocene formation is strictly dependent on the shape of the eroded Carboniferous top surface. In Carboniferous elevated parts, Miocene deposits have the lowest thickness (16 $\mathrm{m})$, whereas in the rest of the area, Miocene thickness is higher $-188 \mathrm{~m}$ in the north and up to $252 \mathrm{~m}$ in the southern part of the area.

\section{Quaternary}

Quaternary deposits cover the entire study area, with thicknesses varying from 6.5 to $39.0 \mathrm{~m}$. Most of the deposits occur as clays, sands and gravels. 
Table 1

Main fault characteristics (Tauron - internal report)

\begin{tabular}{|c|c|}
\hline Longitudinal direction & Throw size / drop direction / dip \\
\hline I western fault & $\mathrm{SSW}-\mathrm{NNE} / 0-15 \mathrm{~m} / 60-70^{\circ}$ \\
\hline I eastern fault & $\mathrm{SSW}-\mathrm{NNE} / 1-15 \mathrm{~m} / 65-70^{\circ}$ \\
\hline II eastern fault & $\mathrm{SSW}-\mathrm{NNE} / 25-90 \mathrm{~m} / 45^{\circ}$ \\
\hline III eastern fault & $\mathrm{SW}-\mathrm{NE} / 3-90 \mathrm{~m} / 50^{\circ}$ \\
\hline IV eastern fault & $\mathrm{N}-\mathrm{S} / 0-20 \mathrm{~m} / 65^{\circ}$ \\
\hline Fault close to seam 327 & Fault zone width $/$ drop direction $/$ dip \\
\hline Latitudinal direction & $30-80 \mathrm{~m} / \mathrm{N} / 85^{\circ}$ \\
\hline I northern fault & $1-15 \mathrm{~m} / \mathrm{N} / 85^{\circ}$ \\
\hline II northern fault & $400 \mathrm{~m} /$ consists of 3 dislocations $>1100 \mathrm{~m}$ drop \\
\hline Jawiszowice fault &
\end{tabular}

The Brzeszcze mine area is located in the fault zone within the Main Syncline, which is an extended synclinal structure running in a NW-SE direction and cut by numerous faults.

The Brzeszcze coal deposit is located in the up-throw of the Jawiszowice fault zone, where coal seams to the depth of 300-500 m below the ground surface were naturally degassed (Fig. 2). Fault tectonics is a very important factor in the entire USCB, influencing the distribution of methane concentrations. The thirteen main dislocations (faults) were found in the area of the Brzeszcze coal deposit. The most important faults are presented in Table 1. The regional, largesize dislocations such as Jawiszowice (Brzeszcze mine), Bzie-Czechowice (Silesia mine) or Książ (Mysłowice-Wesoła mine) fault zones drop the coal seams with high methane content according to the throw direction - southwards (Kędzior et al. 2013). The regional dislocations in the USCB are Variscan structures that are still active (Teper \& Sagan 1995).

The width of the Jawiszowice fault zone is (the southern boundary of the deposit) very large $400 \mathrm{~m}$. It consists of three smaller faults with a total throw of over $1,100 \mathrm{~m}$. In addition to the 13 main faults, there are many numerous smaller dislocations with throws between $0.5-11 \mathrm{~m}$ (Tauron - internal report, Tauron Brzeszcze mine website, Kędzior et al. 2013).
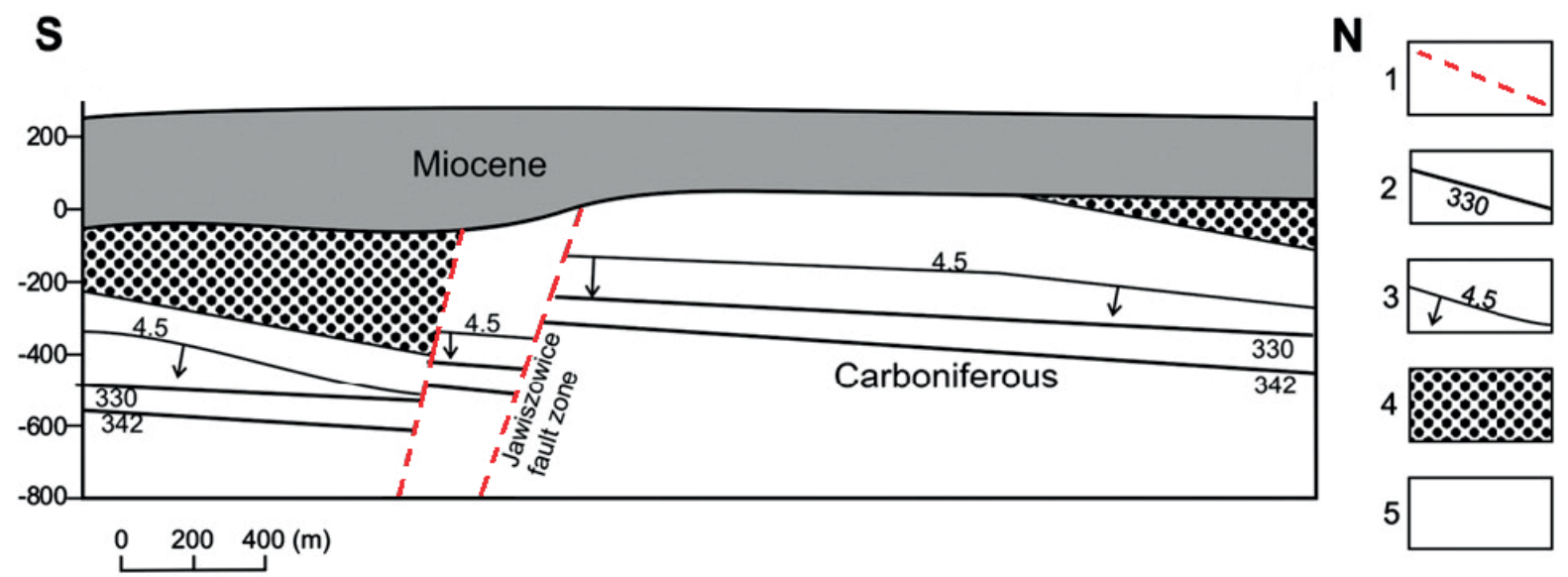

Fig. 2. Schematic cross sections with variations of methane content in Brzeszcze coal mine (Kędzior et al. 2013): 1 - fault zones, 2 - coal seam with identification number, 3 - line of methane content with arrow indicating the direction of increasing values, 4 - Cracow Sandstone Series, 5 - remaining series of the USCB Carboniferous system. Source materials: Archive of Polish Geological Institute 


\section{METHANE CONDITIONS AND THE LAYOUT}

Methane occurs in coal in two forms. In the prevalent, sorbed state, methane is combined with coal physically and chemically due to, inter alia, the van der Waals molecule effect. Methane which has not accumulated in coal micropores migrates through cracks and pores in coal seams and surrounding rocks as a gas in its free state. Methane is released into mining excavations as a result of mining activities which disrupt the pressure equilibrium in the coal seam (Lamberson \& Bustin 1993, Noack 1998, Kotarba 2001, Su et al. 2005, Krasue \& Smoliński 2013, Szlązak et al. 2014, Ju et al. 2016). The research conducted in the Central Mining Institute's Experimental mine Barbara revealed that most of methane emitted to coal workings (60\% average) comes from goafs, overmining and undermining coal seams, but only $40 \%$ of $\mathrm{CH}_{4}$ is emitted from operating longwalls (Krause 2019). All methane emitted during and after mining activities is called coal mining methane (CMM). Even after mine closure, methane can be still emitted to the abandoned coal workings from cracks, fissures, and goafs. The highest methane emissions are observed during current mining works and one month after work liquidation (e.g. Krause \& Karbownik 2019). The most intense and constant emission of methane occurs during mining and related works in longwalls and in the vicinity of gobs. The longwall liquidation period lasts from 1 to 3 months and the volume of emitted methane drops to $20-40 \%$ in relation to the extraction period. After coal mine closuring processes, the total methane emission to the goafs lasts approximately 15 years, constantly decreasing and eventually vanishing completely, but the $\mathrm{CH}_{4}$ emission from the unmined seams can lasts 20 years. (Krause \& Pokryszka 2013, Koptoń \& Wierzbiński 2014, Duda \& Krzemień 2018, Krause 2019).

The progressive concentration of coal production (longer walls, increasing extraction from one wall) contributes to the increase in methane emissions into coal excavations. The slowdown of coal production at greater depths, where methane content and gas pressure are higher, causes an increase in $\mathrm{CH}_{4}$ emissions (Krause \& Eukowicz
1999). Greater concentration of coal extraction increases the real methane hazard (Borowski 1969, Cybulski \& Myszor 1974, Krause 2019, Szlązak et al. 2020). The methane hazard is one of the most widespread natural dangers in Polish and global underground hard coal mining (e.g. Krause \& Smoliński 2013, Lu et al. 2017, Molayemat \& Mohammad Torab 2017, Duda \& Krzemień 2018, Dreger \& Kędzior 2019). Methane is an odourless, colourless, and tasteless gas, lighter than air, it displaces oxygen from the atmospheric air, making it non-breathable. Due to the low oxygen content in the mining atmosphere, miners can suffer from impaired mobility, difficulty in breathing, loss of consciousness and even death (e.g. Honysz 2015). $\mathrm{CH}_{4}$ is also a highly explosive gas when its concentration in the air reaches 5-15\% (e.g. Kozłowski \& Grębski 1982, Frączek 2005, Honysz 2015). To describe the methane hazard, four categories are distinguished in Polish underground hard coal mining regulations. Each category describes the volume of methane $\left[\mathrm{m}^{3}\right]$ in one $\mathrm{Mg}$ of dry ash free coal substance [daf] (Tab. 2) (Regulation of the Ministry of the Environment 2013). Unfortunately, there have been many accidents in the history of Polish coal mining as a result of the ignition and explosion of methane. Some of them are listed in Table 3. Automatic methane measurement systems are obligatory in underground coal workings with II, III and IV category of methane hazard to measure $\mathrm{CH}_{4}$ concentration in the air mixture. When methane concentration in the air exceeds $2 \%$, all electric devices are shut down to prevent sparking from roadheaders etc. miners are also equipped with personal methane meters, which emit an acoustic signal when $\mathrm{CH}_{4}$ concentrations are dangerous. The methane concentration in the air flow duct is determined by methanometers and air samples used for laboratory analysis. Polish health and safety regulations require methane concentrations below $1 \%$ in waste air current and less than $0.75 \%$ in vent shafts (Regulation of the Ministry of the Environment 2013, Honysz 2015, Report 1997-2018). Methane is also a potent greenhouse gas that contributes to global warming, both as a result of human activities (cattle farming, cattle breading, industry) and natural gaseous emissions like peatlands (e.g. Warmuziński 2008, Kirschke et al. 2013, Ghosh et al. 
2015, Kholod et al. 2020, Swolkień 2020). Methane is a 25 to 36 times stronger heat absorbent than carbon dioxide, but it persists in the atmosphere for up to 15 years, while $\mathrm{CO}_{2}$ persists for up to 100 years (Warmuziński 2008, Yusuf et al. 2012, Kędzior 2015, Kholod et al. 2020).

Table 2

Methane hazard categories in Polish hard coal mining (Regulation of the Ministry of the Environment 2013)

\begin{tabular}{|c|c|}
\hline Category & $\begin{array}{c}\text { Methane content } \\
{\left[\mathbf{m}^{3} \mathbf{C H}_{4} / \mathbf{M g} \text { coal }{ }^{\text {daf }}\right]}\end{array}$ \\
\hline Methane-free & $<0.1$ \\
\hline I & $0.1-2.5$ \\
\hline II & $>2.5 \leq 4.5$ \\
\hline III & $>4.5 \leq 8.0$ \\
\hline IV & $\begin{array}{c}>8.0 \text { (or methane and rock } \\
\text { outburst occurred) }\end{array}$ \\
\hline
\end{tabular}

Table 3

Selected accidents in Polish mining caused by methane explosions (Report 1997-2018, State Mining Authority)

\begin{tabular}{|l|c|c|}
\hline \multicolumn{1}{|c|}{ Coal mine } & Fatalities/injured & Year \\
\hline Borynia & $6 / 17$ & 2008 \\
\hline Wujek-Śląsk & $20 / 34$ & 2009 \\
\hline Krupiński & $3 / 11$ & 2011 \\
\hline Mysłowice-Wesoła & $5 / 25$ & 2014 \\
\hline Murcki-Staszic & $1 /-$ & 2016 \\
\hline
\end{tabular}

Carboniferous strata are represented by alternately lying sandstones, mudstones and siltstones with inserts of coal seams. Methane occurs both in its adsorbed form in coal seams, and in free form in coal seams and surroundings rocks. When the underground ventilation system works efficiently, the $\mathrm{CH}_{4}$ released from coal seams and surrounding rocks goes directly to the ventilation shaft and is "unnoticeable" to the miners. Shallow coal beds and rocks are mostly free of methane. As the depth increases, the pore volume decreases and methane content in surrounding rocks decreases too. But if the rock mass is subject to seismic activities and relaxation processes, methane can accumulate in such rocks as sandstones (Krause \& Łukowicz 1999, Krause 2005, 2019). The methane content in Carboniferous rocks (sandstones) that accompany coal seams became an important factor when the extraction of the 510 coal seam began in the Brzeszcze mine. The complex of compact sandstone occurs above both the 510 coal seam and the non-extracted 416 coal seam with high methane content $\left(>8 \mathrm{~m}^{3} \mathrm{CH}_{4} / \mathrm{Mg}\right.$ coal $\left.{ }^{\mathrm{daf}}\right)$ on the 512 production level. The commencement of coal extraction from seam 510, with roof caving, resulted in the disruption of the sandstone package structure and the release of methane, which migrated to higher layers (secondary accumulation), or caused the accumulation of methane in the exploited longwall (Turek 2007, Tauron - internal report). Coal seams are characterised by low porosity and permeability, around $1-3 \mathrm{mD}$, but the sorption capacity is sufficient to absorb more than $20 \mathrm{~m}^{3} \mathrm{CH}_{4} / \mathrm{Mg}$ coal (Kotas 1994, Konopko 2010). The varied and complex geological structure of the Upper Silesian Coal Basin is reflected in the shape of the vertical methane distribution patterns. In general, two types of vertical patterns were recognised - the northern and the southern (Kędzior 2009, Szlązak et al. 2017). In the north, the absence of a hermetic Miocene screen results in the outgassing of the coal seams to the depth of $600-1,000 \mathrm{~m}$. At higher depths, the methane concentration increases rapidly (primary $\mathrm{CH}_{4}$ zone). The southern pattern is characterised by two methane zones with higher methane concentrations. In the topmost of the Carboniferous coal bearing strata, below the thick Miocene cover, secondary accumulation of $\mathrm{CH}_{4}$ is present $\left(>4.5 \mathrm{~m}^{3} \mathrm{CH}_{4} / \mathrm{Mg}\right.$ coal $\left.^{\text {daf }}\right)$. Methane migrated from deeper parts of the strata and mixed with microbial methane. Deeper, the high methane zone becomes thinner, however at the depth of $1200 \mathrm{~m}$ methane content in coal seams increases again, to over $4.5 \mathrm{~m}^{3}$ of $\mathrm{CH}_{4} / \mathrm{Mg}$ coal ${ }^{\text {daf }}$ (primary zone) (e.g. Kotas 1994, Kotarba 2001, Kędzior 2009, Kotarba \& Pluta 2009). At the depth of 2,000 $\mathrm{m}$ and more, rising temperature reduces the sorption capacity of coals (Kędzior 2009).

Studies and analysis carried out in the Brzeszcze coal deposit revealed that methane content in coal seams increases from east to west. Seams operated deeper and located further from the Jawiszowice fault (in northern areas of the deposit) are characterised by lower methane accumulation due to the limited impact of the Jawiszowice fault and the lower $\mathrm{CH}_{4}$ content in the deeper beds. The highest methane accumulations were found in the vicinity of the Jawiszowice fault (in the up-throw 
wing) the largest discontinuity in the Brzeszcze mine area (Tauron - internal report). The occurrence of dislocation zones and related areas with weakened and relaxed rock structures favour the high methane emissions during mining activities and can remodel the horizontal and vertical $\mathrm{CH}_{4}$ distribution in the Carboniferous profile. Faults and rock breaks can also be a natural pathway for the migrating methane. These features are characterised for many coal basins worldwide (e.g. Noack 1998, Thielemann et al. 2001, Karacan et al. 2008, Karacan \& Olea 2014, Szlązak et al. 2014, Molayemat \& Mohammad Torab 2017, Mohtasham Seyfi et al. 2018).

The distribution of methane content is strictly connected with stratigraphy. In the shallow topmost Carboniferous strata, methane was not found - Łaziska layers and Orzesze layers down to coal seam 327 are free of methane, naturally degassed in the geological past. The Łaziska sandstones with high porosity and permeability are the reason of natural coal seams degassing in the upper parts of the deposit (Kędzior et al. 2013). In deeper Orzesze layers, coal seams with high methane content occur only in the bottom part, with the highest $\mathrm{CH}_{4}$ accumulation in seams 347 and $352\left(>7 \mathrm{~m}^{3} \mathrm{CH}_{4} / \mathrm{Mg}\right.$ coall $\left.{ }^{\text {daf }}\right)$. Extremely high methane content was found in the Ruda and Poruba layers, where the highest result was recorded: $21.5 \mathrm{~m}^{3} \mathrm{CH}_{4} / \mathrm{Mg}$ coald ${ }^{\text {daf }}$ in the deepest, 610 bed in the close vicinity of the Jawiszowice fault. The highest methane content coal seams occur in the range of $1,000 \mathrm{~m}$ of the fault, proving the high permeability character of the Jawiszowice fault. The average methane content for the entire Brzeszcze coal deposit is $6.546 \mathrm{~m}^{3} \mathrm{CH}_{4} / \mathrm{Mg}$ coal ${ }^{\text {daf }}$ (Tauron - internal report).

\section{RESULTS AND DISCUSSION}

\section{Hard coal output}

The historical data for the Brzeszcze mine shows hard coal output from 1988 to 2018 (Fig. 3). The overall production trend is decreasing, with two increase periods. In 1988, the coal output was the highest within the research period - 3.85 million Mg. In 1993, coal extraction dropped to under to under 3 million $\mathrm{Mg} /$ year and then constantly but slightly decreased to reach 2.09 million $\mathrm{Mg}$ of extracted coal by 2003 . One year later, the output was a little higher - 2.41 million $\mathrm{Mg}$, but in succeeding years it decreased from 1.73 million $\mathrm{Mg}$ (2005) to 1.03 million Mg in 2010. During the next two years (2011-2012) coal production rose over $70 \%$ in comparison to 2010. In 2015, the lowest coal production was recorded - only 0.76 million Mg. During the entire coal output research period (1998-2018) the Brzeszcze mine extracted 65.19 million Mg of coal.

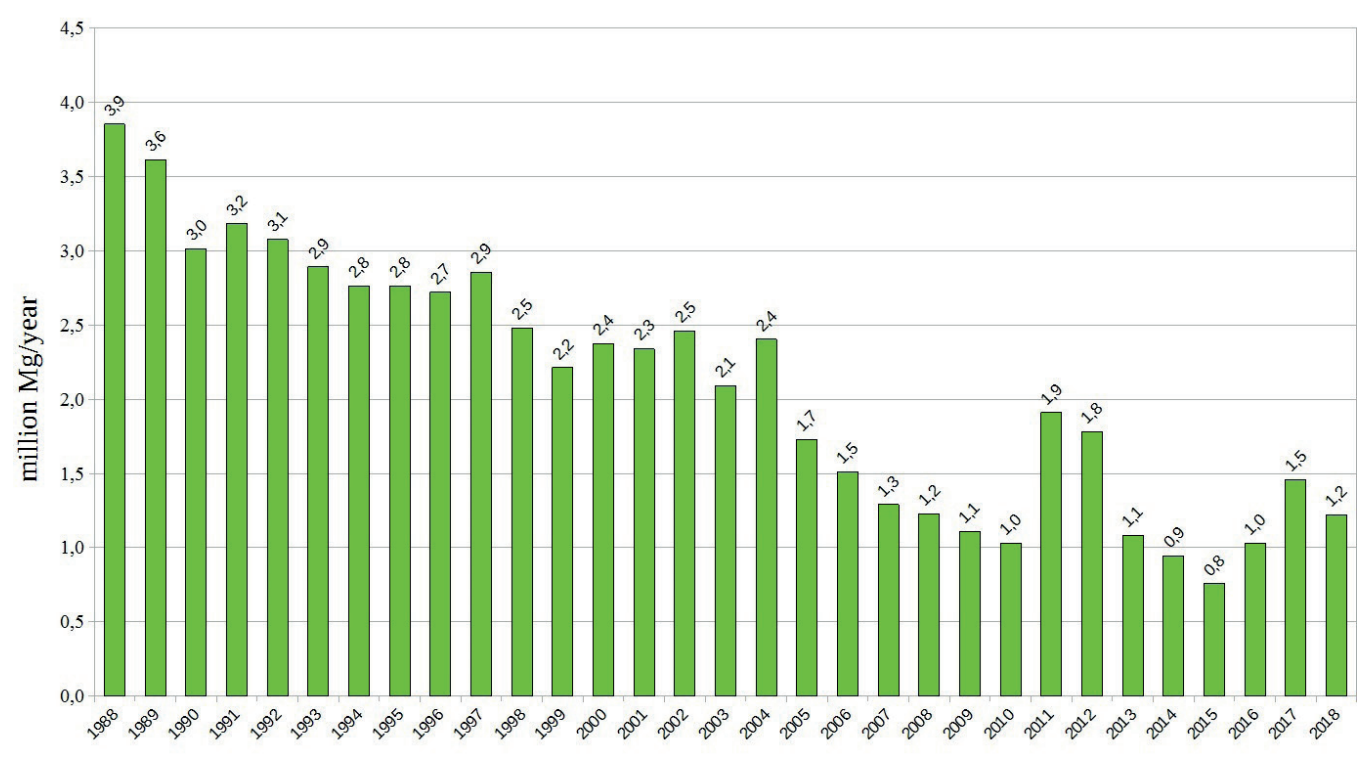

Fig. 3. The hard coal output in 1988-2018 in Brzeszcze mine (Tauron - internal report, Report 1995-2018) 
In 2000-2004, the Brzeszcze mine carried out mining operations in the $347,349,352,353,356$, $364,401,405 / 1,510,610$ coal seams (Tab. 4). In 2004-2016/2017, production took place in coal seams: 352, 364, 401, 405/1, 510 between 740 and $900 \mathrm{~m}$ below the ground surface. Since 2016/2017 only two coal seams have been operated (364 and 510). Hitherto, the wall length in the 364 coal seam was $250 \mathrm{~m}$, in future years the length is designed at $200 \mathrm{~m}$ with the average wall run set at $900-800 \mathrm{~m}$. The 510 coal seam is located between 740 and $1,000 \mathrm{~m}$ below ground level. The walls, operating between 740 and $900 \mathrm{~m}$ levels, are characterised by 750-1,000 m wall runs. Below $900 \mathrm{~m}$, the designed longwall run oscillated around $1,400 \mathrm{~m}$. The longwall length in the 510 coal seam varies from 160 to $200 \mathrm{~m}$ with a coal seam thickness 1.1-7.5 m (Tauron - internal report, Tauron Brzeszcze mine website). Throughout the entire research period (date range for operating walls is 2004-2018/19) the longwall heights (1.4-4.5 m), lengths $(145-250 \mathrm{~m})$ and runs $(280-1,452 \mathrm{~m})$ changed depending on the year, the coal production level (depth) and the type of coal extracted (coal seam group). There is no correlation between mining factor changes and coal production depth or stratigraphy.

In the Brzeszcze mine, hard coal is extracted under very unfavourable methane conditions, mostly classified as IV category of methane hazard (Regulation of the Ministry of the Environment 2013) where $\mathrm{CH}_{4}$ can be released very easily during mining activities. In the past, the coal was extracted from methane-free, naturally degassed depths - 170, 230, 260 and $360 \mathrm{~m}$ in the northern part of the deposit. Historical sources state that in 1964 the first large methane emission to coal excavations was reported -23.23 million $\mathrm{m}^{3}$ in a year due to mining activities started at the depth of $430 \mathrm{~m}$ below ground level (Tauron - internal report). The vertical distribution of methane accumulation (the average values) shows that highly methane bearing seams $\left(>4.5 \mathrm{~m}^{3} \mathrm{CH}_{4} / \mathrm{Mg}\right.$ coal $\left.{ }^{\text {daf }}\right)$ occur at the approx. $450 \mathrm{~m}$ below ground level and deeper (Fig. 4). During the coal seam relaxation processes caused by coal mining, methane was emitted to coal excavations, aggravating the methane hazard. In effect, total $\mathrm{CH}_{4}$ emissions more than doubled, to 54.41 million $\mathrm{m}^{3}$ in 1974 (Tauron - internal report). In the vertical profile, methane content in seams increases with depth (Fig. 4). The methane content gently increases to $900 \mathrm{~m}$ below the ground level, where most of the $\mathrm{CH}_{4}$ has accumulated - over $20 \mathrm{~m}^{3} \mathrm{CH}_{4} / \mathrm{Mg}$ coald ${ }^{\text {daf }}$. At greater depths, a decrease in methane accumulation in coal is observed. The methane content decreases to 14-15 $\mathrm{m}^{3} \mathrm{CH}_{4} / \mathrm{Mg}$ coal $^{\text {daf }}$ at $1,000 \mathrm{~m}$ below the ground level and the $\mathrm{CH}_{4}$ accumulation remains constant at deeper parts of the deposit (Fig. 4). Coal mining activities carried out close to the Jawiszowice fault resulted in methane emission increases. The highest total $\mathrm{CH}_{4}$ emission was recorded (124.80 million $\mathrm{m}^{3}$ in 1997) when coal was mined in the close vicinity of the fault. When the coal mining activities moved further from the fault, total $\mathrm{CH}_{4}$ emissions generally decreased.

Table 4

Mining level characteristics (Tauron - internal report, Tauron Brzeszcze mine website)

\begin{tabular}{|l|c|c|}
\hline \multicolumn{1}{|c|}{$\begin{array}{c}\text { Mining level } \\
\text { [m below ground level] }\end{array}$} & $\begin{array}{c}\text { Elevation } \\
\text { [m above sea level] }\end{array}$ & Coal bed access \\
\hline 109 (closed) & +153.40 & $215,301-318$ \\
\hline 170 (closed) & +92.20 & $215,301-334$ \\
\hline 230 (closed) & +35.60 & $215,301-346$ \\
\hline 360 (ventilation) & -96.40 & $334-346$ \\
\hline 430 (ventilation) & -171.50 & $305-364,401-416$ \\
\hline 512 (ventilation) & -248.60 & $334-364,401-416,510,610$ \\
\hline 640 (main extraction level) & -378.00 & $334-364,401-416,510,610$ \\
\hline 740 (extraction/auxiliary level) & -478.00 & $334-364,401-416,510,610$ \\
\hline 900 (extraction/auxiliary level) & -640.30 & $346-347,352-364,510,401-416,610$ \\
\hline
\end{tabular}




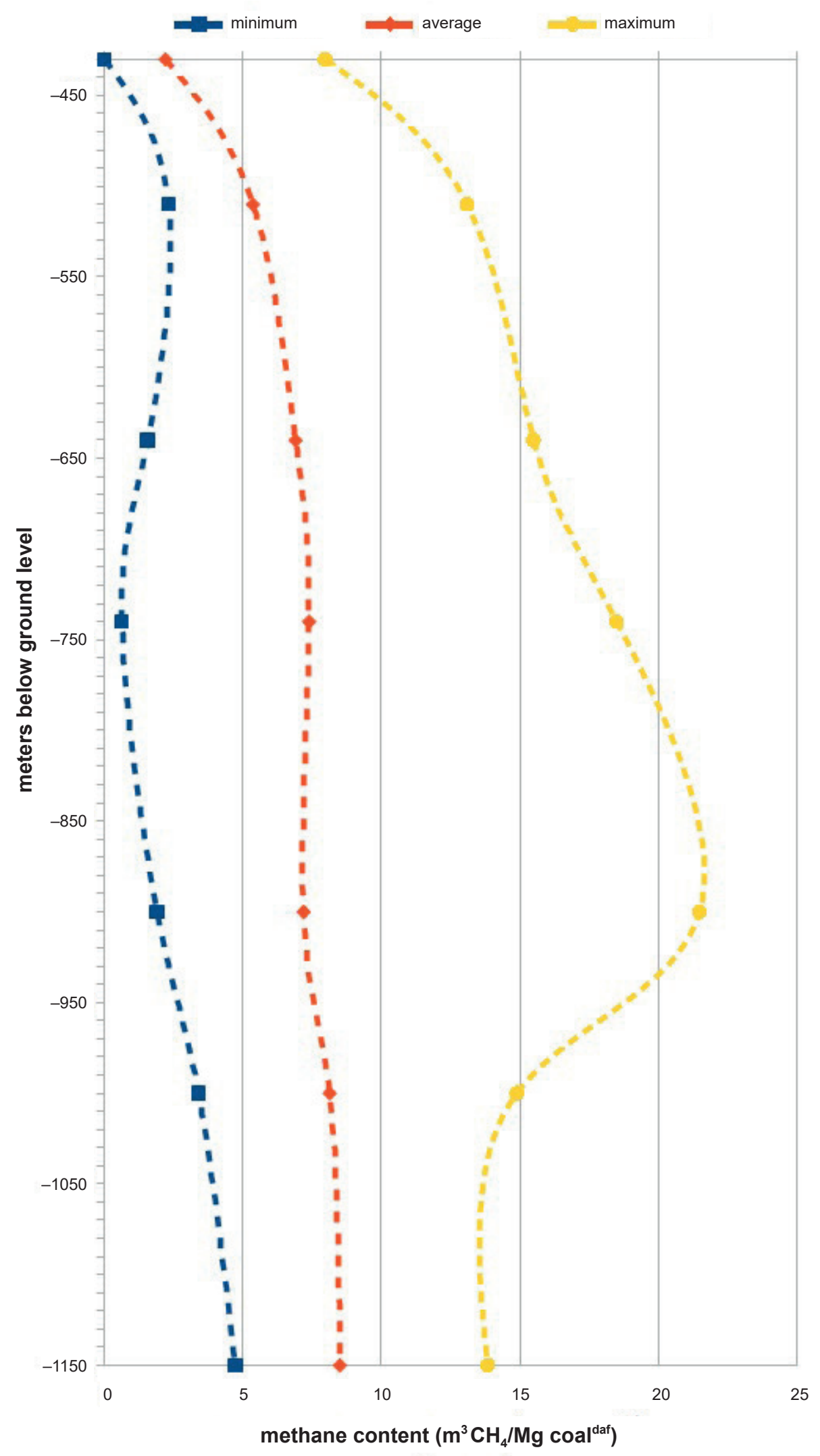

Fig. 4. Simplified vertical distribution of the methane content in the Brzeszcze mine (Tauron - internal report) 


\section{Absolute methane emissions}

These studies cover the 1997-2018 time period, when the Brzeszcze mine changed the model and structure of its coal production. Since 1997, the Brzeszcze coal mine has been working as an individual enterprise. In previous years, the Brzeszcze mine was combined with the Ruch II Jawiszowice, but after coal resources depleted (to 512 production level), Ruch Jawiszowice II was closed. In the late 1990's, the Brzeszcze coal mine decreased the number of operating walls - from 14 to 2 , extending its length to $250 \mathrm{~m}$ and the wall run to $400-1,400 \mathrm{~m}$ at the same time (Tauron - internal report). These changes improved the coal output from one wall, but the total hard coal production decreased every year. The methane emission variations have changed twofold. Methane emissions into coal excavations increased due to output concentration from one longwall - longer walls and faster mining activities (underground preparations, roadheaders works and coal exploitation) favours the release of $\mathrm{CH}_{4}$ from relaxed coal and surrounding rocks to the operating coal workings (Krause \& Łukowicz 1999, Turek 2007, Krause 2019). On the other hand, total methane emissions have decreased due to the substantial decrease in total coal production (Figs. 3, 5) (Krause \& Łukowicz 1999, Turek 2007, Tauron - internal report). In the period studied (1997-2018), the absolute methane emission did not change significantly. From 1997 to 2005 a constant but gentle decline was observed - from 124.80 to 101.04 million $\mathrm{m}^{3}$ /year (Fig. 5). In the following years (20062009), an increase in total $\mathrm{CH}_{4}$ emission was recorded. In 2006-107.37 million $\mathrm{m}^{3}$ of methane was released into mine excavations. Three years later, the emission increased by $13 \%$ to 121.65 million $\mathrm{m}^{3}$ of methane. In succeeding years (20102015), the total emission dropped again, from over 116 million $\mathrm{m}^{3}$ to 75.61 million $\mathrm{m}^{3}$ in 2015 . It was the lowest, recorded volume of emitted $\mathrm{CH}_{4}$ in the entire research period. During the last three years of covered by the studies, the volume of released methane increased, to more than 100 million $\mathrm{m}^{3}$ in 2018. The main reasons for the slight decrease of $\mathrm{CH}_{4}$ emission during the research period were preparatory works limitation and total coal output decrease. An additional cause was the closure of the 510 coal seam by putting dams (in 2012) at the 740 production level, due to an endogenous fire (Tauron - internal report).

In recent years, coal extraction operations were carried out at a greater distance from the Jawiszowice fault, and at greater depths (in lower methane bearing seams), which caused a reduction in methane emissions (Fig. 5) (Krause \& Łukowicz 1999, Tauron - internal report, Report 1997-2018).

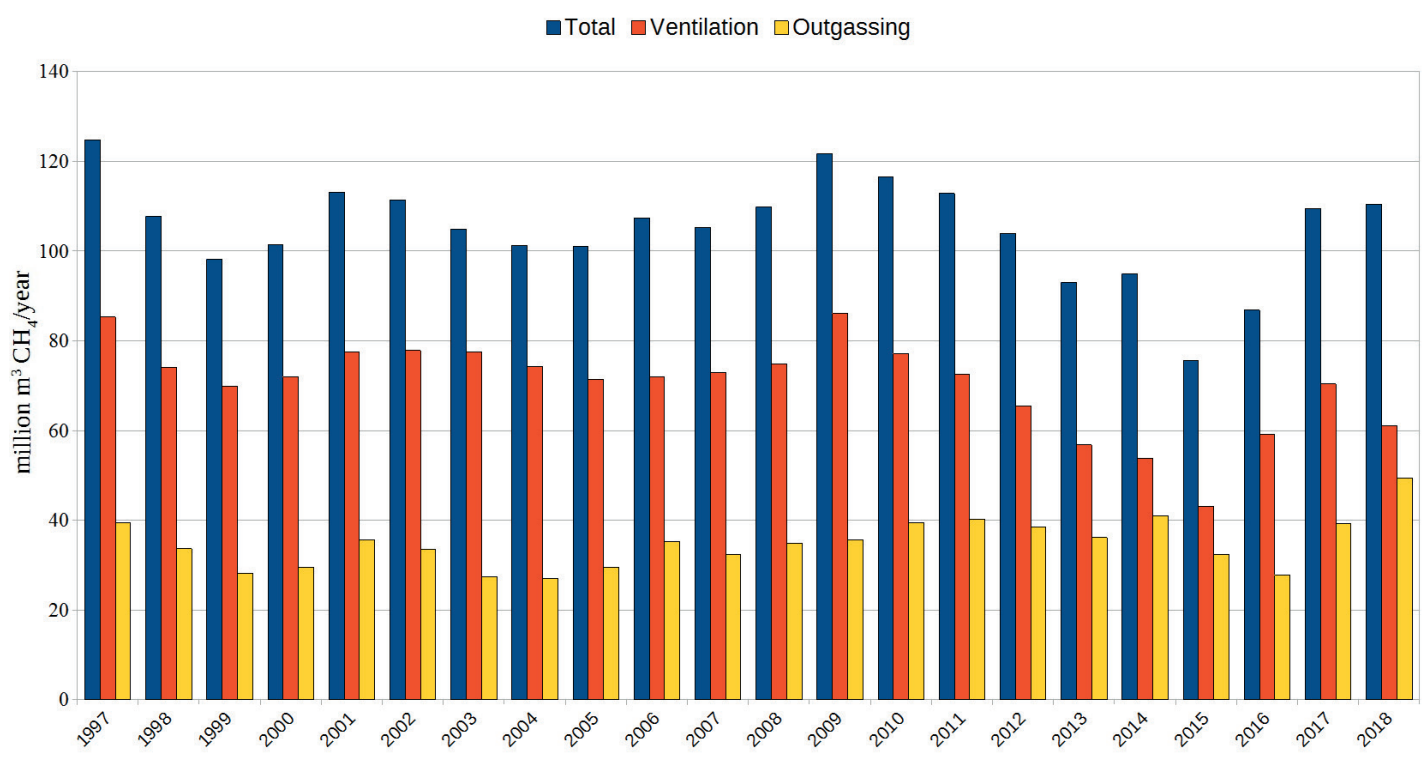

Fig. 5. The absolute methane emission (total), VAM emission and outgassing in Brzeszcze mine in 1997-2018 (Tauron - internal report) 
During the same period (1997-2018) the total methane emissions in the Upper Silesian Coal Basin constantly increased. From 1998 to $2008, \mathrm{CH}_{4}$ emissions increased from 722.18 to 880.9 million $\mathrm{m}^{3}$. After that, there was a four-year period (2009-2012) when methane emissions dropped to 828.24 million $\mathrm{m}^{3}$, but in succeeding years, up to the end of the study, the absolute methane emission increased constantly, exceeding 900 million $\mathrm{m}^{3}$ in 2015 (Report 1997-2018, Dreger 2019, Kędzior \& Dreger 2019).

\section{Ventilation air methane emission, outgassing and specific methane emission}

All methane released into mine excavations (CMM) needs to be utilised in order to keep the mining atmosphere free of methane and safe for conducting operations. The easiest and quickest way is to discharge the "spent", warmed up and enriched in gases (e.g $\mathrm{CH}_{4}$ ) air mixture out of the mine, or to a place in the ventilation network where it does not pose a danger to the workers. The underground ventilation network is constantly at work, replacing spent, warmed up air mixture rich in methane and other gases with a new, colder and fresh one. The air exchange processes not only helps to keep the atmosphere free of methane, but also ensures that air temperatures are as low and comfortable as possible (Frączek 2005, Honysz 2015). The second, very useful and often applied way to keep a working mine free of $\mathrm{CH}_{4}$ is degassing (methane drainage), which leads to the drainage of as much of the coal-beds gases as possible (e.g. Karacan et al. 2011, Obracaj \& Swolkień 2016). The collected methane can be used in internal mining processes to produce heat or to cool things, it can be sold to external customers or released to the atmosphere (e.g. Frączek \& Frączek 2004, Karacan et al. 2011, Szlązak et al. 2014, Szlązak 2015). Beside ventilation air methane and degassing, $\mathrm{CH}_{4}$ can be captured from virgin (unmined) coal seams - coal bed methane (CBM) (90-98\% of $\left.\mathrm{CH}_{4}\right)$ or from abandoned coal workings when methane is still being emitted from diffuse vents, cracks or fissures (Kozłowski \& Grębski 1982, Honysz 2015, Duda \& Krzemień 2018, Krause \& Karbownik 2019, Kholod et al. 2020, Coal Mine Methane Sources). The methane emitted or produced during mining activities (CMM) can be utilised in many ways, providing benefits such as: reducing greenhouse gas emissions, increasing mine safety or delivering valuable fuel for power and heat generation. CMM is gathered by drilling small diameter boreholes from: underground working faces, during coal preparatory works and exploitation (66\%), from goafs (32\%) and pre-mining drainage (2\%). An underground pipeline system delivers the collected gas mixture to surface degasification stations. The collected gas mixture, rich in $\mathrm{CH}_{4}$, can be used in VAM gas enrichment, power, heat production or cooling, or it can be injected into natural gas pipelines. Not all of the methane gathered is used. In the Upper Silesian Coal Basin, methane use efficiency is around $55-60 \%$, with the rest of the unused gas being released directly into the air, contributing to greenhouse gas (GHG) emissions (Karacan et al. 2008, Karacan et al. 2011, Patyńska 2013, Obracaj \& Swolkień 2016, Dreger 2019, Kędzior \& Dreger 2019, Swolkień 2020). The CBM drainage supports the forthcoming exploitation under much safer conditions, in partly degassed/drained coal seams. These types of action also bring valuable environmental benefits such as reducing greenhouse gas emissions and providing a source of energy (e.g. Chunshan et al. 2019).

Coal bed methane for power generation is extracted in the USCB region on a small, regional scale. A gas-powered unit has been installed in Gilowice (in the municipality of Miedźna, region of Silesia), where since 2016 PGNiG (Polish Oil and Gas Company), in partnership with the Polish Geological Institute, has been carrying out the "Geo-Methane" CBM research project (Jureczka et al. 2018). The unit is operating at the Gilowice-1 borehole site, producing electricity for the Tauron Distribution power grid. The purpose of the Geo-Methane experimental project is to explore the applicability of hydraulic fracturing to CBM production prior to coal exploitation in a given area. Thanks to this project, future coal mining will be carried out under safer methane conditions. The test production run by the Polish Oil and Gas Company in 2017 yielded close to $900,000 \mathrm{~m}^{3}$ of gas. The CBM reserves in the USCB are estimated at 170 billion $\mathrm{m}^{3}$ (PGI 2018, PGNiG News 2019, Wojsa 2019).

In the Brzeszcze mine, the breakdown between VAM emission and outgassing is around $65 / 35$. The research period began in 1997, when 85 million $\mathrm{m}^{3}$ of $\mathrm{CH}_{4}$ was emitted directly into 
the atmosphere due to the VAM emission process (Fig. 5). Over the next 11 years (1998-2008), the volume of the released methane varied from 69.95 to over 77 million $\mathrm{m}^{3}$ per year. In 2009, an increase was noticed $\left(86.04\right.$ million $\left.\mathrm{m}^{3}\right)$ - it was the highest VAM emission volume in the entire research history. In subsequent years (2010-2015), the volume of methane emissions into the atmosphere halved to 43 million $\mathrm{m}^{3}$ in 2015 . Until the end of the study period (2016-2018) VAM emission increased, but it did not exceed 71 million $\mathrm{m}^{3}$.

In the Upper Silesian Coal Basin $25 \%$ of the methane emitted is captured by underground drainage (outgassing), while the remainder (75\%) escapes directly into the atmospheric air as VAM emission (Dreger 2019, Dreger \& Kędzior 2019, Report 1997-2018). In the Brzeszcze mine 35\% of released methane is captured in outgassing processes. Methane has been captured directly from coal seams with high methane content $352,364,510$, abandoned excavations and goafs. During the entire research period (1997-2018), the annual degassing volume fluctuated between 27 and 40 million $\mathrm{m}^{3}$ of captured methane (Fig. 5). From 2003 to 2011, an increase in degassing was observed - from over 27 to 40.27 million $\mathrm{m}^{3}$ of collected $\mathrm{CH}_{4}$. After that period, degassing varied from 27.68 to 41 million $\mathrm{m}^{3}$ of $\mathrm{CH}_{4}$. The highest volume of captured methane was recorded in the last year of the study period (2018), when almost 50 million $\mathrm{m}^{3}$ was collected by the underground drainage system. The Brzeszcze mine used to sell or transfer the collected gas to, inter alia, a chemical plant located in the vicinity of the mine or used it in coal boiler burners. At present, all of the collected methane is sold to a nearby heat and power plant. The methane use efficiency in the Brzeszcze mine is the highest in the entire USCB, ranging from 95 to 100\% (Nawrat et al. 2006, Tauron - internal report).

The real methane hazard in working mines can be shown in terms of the specific methane emission. It is the total methane emission related to the overall hard coal output given as $\mathrm{m}^{3} \mathrm{CH}_{4} / \mathrm{Mg}$ coal. From 1997 to 2004 the specific $\mathrm{CH}_{4}$ emission varied from 42 to $50 \mathrm{~m}^{3} \mathrm{C} \mathrm{H}_{4} / \mathrm{Mg}$ coal (Fig. 6). In the following years, the absolute methane emission was at a similar level, but hard coal output was decreasing. As a result, the specific $\mathrm{CH}_{4}$ emission increased from $58 \mathrm{~m}^{3} \mathrm{CH}_{4} / \mathrm{Mg}$ coal in 2005 and was almost doubled in 2010 when $113.09 \mathrm{~m}^{3}$ of $\mathrm{CH}_{4}$ was emitted for every single $\mathrm{Mg}$ of coal extracted. In the period 2011-2013, the specific methane emission decreased but during the last 5 years of the study period the emission fluctuated between 75 and $100 \mathrm{~m}^{3} \mathrm{CH}_{4} / \mathrm{Mg}$. In the entire Upper Silesian Coal Basin, the specific methane emission has been constantly rising every year due to greater methane emissions from USCB coal mines, with coal output decreasing at the same time. Since 2014, over $14 \mathrm{~m}^{3}$ of $\mathrm{CH}_{4}$ is being emitted per one Mg of coal (Dreger \& Kędzior 2019).

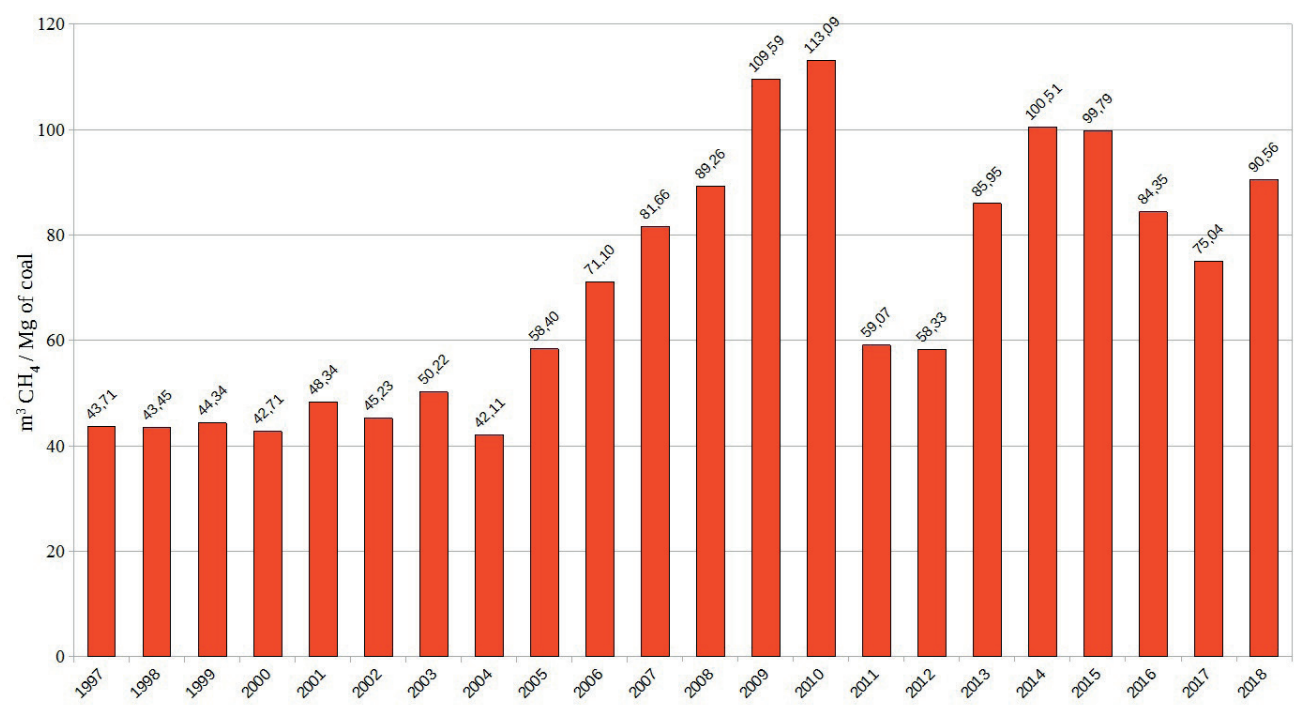

Fig. 6. Specific methane emissions in the Brzeszcze mine in 1997-2018 (Tauron - internal report) 


\section{SUMMARY}

The Brzeszcze mine produces hard coal for power production from the Brzeszcze coal deposit located in the Upper Silesian Coal Basin in Poland. The upper coal seams, which were depleted in the past, were free of methane or the $\mathrm{CH}_{4}$ content was too low to pose any real danger. Now, the Brzeszcze coal mine is characterised by one of the highest methane emissions into coal workings in the entire USCB. The most important natural factors forming methane content and emission are the lithology of the Carboniferous coal bearing strata (the upper parts of the deposit were naturally degassed due to the highly porous Łaziska sandstones) and fault zone occurrence (Jawiszowice). The methane distribution in the coal deposit has mainly been shaped by the Jawiszowice fault - the regional dislocation which has oriented the coal bearing strata according to the throw direction southwards. The high permeability of the Jawiszowice fault and secondary methane accumulation in the beds are reflected in higher methane concentrations in seams close to the dislocation. Mining activities, such as preparatory works or coal extraction, carried out in the seams located close to the Jawiszowice fault, are burdened by high methane emissions into the mining excavations from coal, surrounding rocks, and the underlying and overlying strata. Further from the fault, the $\mathrm{CH}_{4}$ content decreases. Mining works located further from the Jawiszowice fault and on greater depths, where $\mathrm{CH}_{4}$ content is lower (deeper than $740 \mathrm{~m}$ below ground level) are characterised by lower methane emissions into mining excavations. The mining factors (longwall heights, runs and lengths) are of minor importance and have no measurable effect on the volume of methane emissions. There is no correlation between mining factor changes and coal production depth or stratigraphy. The analysed period covered the years 1998-2018 for coal production and 1997-2018 for methane emissions. The overall hard coal output was reduced threefold from 3.9 to 1.2 million $\mathrm{Mg}$ /year, while the absolute/total methane emission from coal seams usually exceeded 100 million $\mathrm{m}^{3}$ annually. The reduction of coal production, combined with high volumes of methane released into coal workings every year, results in the high specific methane emission values (over $40 \mathrm{~m}^{3} \mathrm{CH}_{4} / \mathrm{Mg}$ coal).

This study was undertaken in the framework of the activities of the University of Silesia in Katowice and was funded by the University of Silesia, Institute of Earth Sciences (WNP/INOZ/2020_ZB32). The author is grateful to the employees of Central Mining Institute in Katowice and the employees of Tauron Wydobycie - Brzeszcze mine: Mr. Adam Wójcik and Marcin Koryciński for their kind cooperation and leads during data collection for this research.

\section{REFERENCES}

Bałuk W. \& Wyrwicki R., 1972. Geologia. Wydawnictwa Geologiczne, Warszawa.

Borowski J., 1969. Zależność gazowości ścian od wielkości wydobycia. Prace GIG, Komunikat nr 472, GIG, Katowice.

Chunshan Z., Bingyou J., Sheng X., Zhongwei C. \& He L., 2019. Coalbed methane emissions and drainage methods in underground mining for mining safety and environmental benefits: A review. Process Safety and Environmental Protection, 127, 103-124.

Coal Mine Methane Sources. Coalbed Methane Outreach Program, Coal Mine Methane Sources. https://www.epa. gov/cmop/coal-mine-methane-sourcesavailable [access: 2.02.2020]

Cybulski K. \& Myszor H., 1974. Próba określenia ogólnej zależności wydzielania metanu od wielkości wydobycia. Archiwum Górnictwa, 27, 2.

Doktorowicz-Hrebicki S. \& Bocheński T., 1952. Podstawy i niektóre wyniki pararelizacji pokładów węgla w Zagłębiu Górnośląskim. Geologiczny Biuletyn Informacyjny, 1, 13-14.

Duda A. \& Krzemień A., 2018. Forecast of methane emission from closed undergroundcoal mines exploited by longwall mining - a case study of Anna coal mine. Journal of Sustainable Mining, 17, 184-194.

Dreger M., 2019. Methane emission in selected hard-coal mines of the Upper Silesian Coal Basin in 1997-2016. Geology, Geophysics \& Environment, 45, 2, 121-132.

Dreger M. \& Kędzior S., 2019. Methane emissions and demethanation of coal mines in the Upper Silesian Coal Basin between 1997 and 2016. Environmental \& Socio-Economic Studies, 7, 1, 12-23

Euracoal, 2019. EURACOAL STATISTICS Coal and lignite production and imports in Europe. https:/euracoal.eu/ info/euracoal-eu-statistics/ [access: 1.04.2020].

Frączek R., 2005. Zwalczanie zagrożenia metanowego w kopalniach węgla kamiennego. Katedra Elektryfikacji i Automatyzacji Górnictwa Politechniki Śląskiej, Gliwice.

Frączek R. \& Frączek J., 2004. Obliczenie wydajności emisji metanu $\mathrm{z}$ otworów odmetanowania górotworu w ścianach kopalń węgla kamiennego. Przegląd Górniczy, 60, 11, 54-62. 
Geological and Mining Law, 2011. Ustawa $z$ dnia 9 czerwca 2011 r. - Prawo geologiczne i górnicze. Dz.U. 2011 nr 163, poz. 981 with amendments.

Ghosh A., Patra P.K., Ishijima K., Umezawa T., Ito A. et al., 2015. Variations in global methane sources and sinks during 1910-2010. Atmospheric Chemistry and Physics, $15,5,2595-2612$.

Hunt J.M., 1979. Petroleum Geochemistry and Geology. W.H. Freeman, San Francisco.

Honysz J., 2015. Górnictwo 2. Wydawnictwo Naukowe "Śląsk", Katowice.

Ju Y., Sun Y., Sa Z., Pan J., Wang J., Hou Q., Li Q., Yan Z. \& Liu J., 2016. A new approach to estimate fugitive methane from coal mining in China. Science of the Total Environment, 543( $\mathrm{Pt} \mathrm{A})$, 514-523.

Jureczka J. \& Kotas A., 1995. Upper Silesian Coal Basin. [in:] Zdanowski A. \& Żakowa H. (eds.), The Carboniferous System in Poland, PIG, Warszawa, 164-172.

Jureczka J., Kasza P. \& Kroplewski Ł., 2018. Pre-mine drainage of methane from coal seams in the USCB-Geo-Methane Program. XXVII School of Underground Mining Session - Coal Mine Methane as a Valuable Energy Source Krakow, February $28^{\text {th }} 2018$. https://www.unece. org/fileadmin/DAM/energy/images/CMM/CMM_CE/ SEP_-_11._Pre-mine_Drainage_of_Methane_from_ Coal_Seams_in_the_USCB_\%E2\%80\%93_Geo-Methane_Program.pdf [access: 2.07.2020].

Karacan C.Ö. \& Olea R.A., 2014. Inference of strata separation and gas emission paths in longwalloverburden using continuous wavelet transform of well logs and geostatistical simulation. Journal of Applied Geophysics, 105, 147-158.

Karacan C.Ö., Ulery J.P. \& Goodman G.V.R., 2008. A numerical evaluation on the effects of impermeable faults on degasification efficiency and methane emissions during underground coal mining. International Journal of Coal Geology, 75, 195-203.

Karacan C.Ö., Ruiz F.A., Cotè M. \& Phipps S., 2011. Coal mine methane: A review of capture and utilization practices with benefits to mining safety and to greenhouse gas reduction. International Journal of Coal Geology, 86, 121-156.

Keqdzior S., 2009. Accumulation of coal-bed methane in the south-west part of the Upper Silesian Coal Basin (southern Poland). International Journal of Coal Geology, 80, 20-34.

Kędzior S., 2015. Emission and commercial utilization of coal mine methane in the Upper Silesian Coal Basin illustrated by the example of Katowice Coal Holding Company. Environmental \& Socio-Economic Studies, 3, $1-10$.

Kędzior S. \& Dreger M., 2019. Methane occurrence, emissions and hazards in the Upper Silesian Coal Basin, Poland. International Journal of Coal Geology, 211, 103226.

Kędzior S., Kotarba M.J. \& Pękała Z., 2013. Geology, spatial distribution of methane content and origin of coalbed gases in Upper Carboniferous (Upper Mississippian and Pennsylvanian) strata in the south-eastern part of the Upper Silesia Coal Basin, Poland. International Journal of Coal Geology, 105, 24-35.

Kholod N., Evans M., Pilcher R.C., Roschanka V., Ruiz F., Cote M. \& Collings R., 2020. Global methane emissions from coal mining to continue growing even with declining coal production. Journal of Cleaner Production, 256, 120489.

Kirschke S., Bousquet P., Ciais P., Saunois M., Canadell J.G. et al., 2013. Three decades of global methane sources and sinks. Nature Geoscience, 6, 813-823.

Konopko W. (red.), 2010. Warunki bezpiecznej eksploatacji pokładów węgla zagrożonych metanem, tąpaniami i pożarami endogenicznymi. Główny Instytut Górnictwa, Katowice.

Koptoń H. \& Wierzbiński K., 2014. The balance of methane and ventilation as a tool for methane hazard assessment in the areas of longwalls exploited in hard coal mines. Journal of Sustainable Mining, 13, 4, 40-46.

Kotas A., 1990. Upper Silesian Coal Basin. [in:] Osika R. (ed.), Geology of Poland. Vol. 6: Mineral Deposits, Wydawnictwa Geologiczne, Warszawa, 77-92.

Kotas A. (ed.), 1994. Coal-bed Methane Potential of the Upper Silesian Coal Basin, Poland. Prace Państwowego Instytutu Geologicznego, 142, PIG, Warszawa.

Kotarba M.J., 2001. Composition and origin of gases in the Upper Silesian and Lublin coal basins, Poland. Organic Geochemistry, 32, 1, 163-180.

Kotarba M.J. \& Pluta I., 2009. Origin of natural waters and gases within the Upper Carboniferous coal-bearing and autochthonous Miocene strata in south-western part of the Upper Silesian Coal Basin, Poland. Applied Geochemistry, 24, 5, 876-889.

Kozłowski B. \& Grębski Z., 1982. Odmetanowanie górotworu w kopalniach. Wydawnictwo "Śląsk", Katowice.

Krause E., 2005. Czynniki kształtujące wzrost zagrożenia metanowego w ścianach o wysokiej koncentracji wydobycia. Przegląd Górniczy, 61, 9, 19-26.

Krause E., 2019. Zagrożenie metanowe $w$ kopalniach węgla kamiennego. Główny Instytut Górnictwa, Katowice.

Krause E. \& Karbownik M., 2019. Tests of methane desorption and emission from samples of hard coal in the context of mine closures through flooding. Journal of Sustainable Mining, 18, 127-133.

Krause E. \& Łukowicz K., 1999. Zagrożenia metanowe. [in]: Dubiński J. (red.), Koncentracja wydobycia a zagrożenia górnicze, Główny Instytut Górnictwa, Katowice.

Krause E. \& Pokryszka Z., 2013. Investigations on methane emission from flooded workings of closed coal mines. Journal of Sustainable Mining, 12, 2, 40-45.

Krause E. \& Smoliński A., 2013 Analysis and assessment of parameters shaping methane hazard in longwall areas. Journal of Sustainable Mining, 12, 13-19.

Lamberson M.N. \& Bustin R.M., 1993. Coalbed methane characteristics of Gates Formation coals, northeastern British Columbia: effect of maceral composition. AAPG Bulletin, 77, 2062-2076.

Lu Y., Akhtar S., Sasmito A.P. \& Kurnika J.C., 2017. Prediction of air flow, methane, and coal dust dispersion in a room and pillar mining face. International Journal of Mining Science and Technology, 27, 657-662.

Mohtasham Seyfi M., Khademi Hamidi J., Monjezi M. \& Hosseini A., 2018. Estimation of coal seams gas content for evaluating potential use of methane drainage system in Tabas coal mine. Journal of Mining \& Environment, 9, 3, 667-677. https://doi.org/10.22044/jme.2018.6783.1501. 
Molayemat H. \& Mohammad Torab F., 2017. Evaluation of coalbed methane potential in Parvadeh IV coal deposit in central Iran using a combination of MARS modeling and Kriging. Journal of Mining \& Environment, 8, 2, 305-319. https://doi.org/10.22044/jme.2017.874.

Nawrat S., Kuczera Z., Łuczak R., Napieraj S. \& Życzkowski P., 2006. Gospodarcze wykorzystanie metanu z odmetanowania pokładów węgla polskich kopalń węgla kamiennego. Górnictwo i Geoinżynieria, 30, 2, 35-51.

Noack K., 1998. Control of gas emissions in underground coal mines. International Journal of Coal Geology, 35, 57-82.

Obracaj D. \& Swolkień J., 2016. Method of methane drainage with using the cased long boreholes. Economic Commission for Europe Committee on Sustainable Energy Group of Experts on Coal mine Methane. Eleventh session, Geneva, 24-25 October 2016. https://www.unece. org/fileadmin/DAM/energy/se/pp/coal $/ \mathrm{cmm} / 11 \mathrm{cmm}$ oct2016/a9_Methane.drainage_Poland_OBRACAJ_ SWOLKIEN.pdf [access: 01.09.2020].

Patyńska R., 2013. Methane emissions from ventilation and degasification systems of hard coal mines in Poland in the years 2001-2010. Gospodarka Surowcami Mineralnymi, 29, 1, 17-33.

PGI, 2018. Nasze doświadczenia $w$ zakresie pozyskiwania metanu z pokładów węgla prezentowane w Bogocie. Państwowy Instytut Geologiczny - Państwowy Instytut Badawczy. https://www.pgi.gov.pl/aktualnosci/display/10885-nasze-doswiadczenia-w-zakresie-pozyskiwania-metanu-z-pokladow-wegla-prezentowane-w-bogocie.html [access: 1.03.2020].

PGNiG News, 2019. Coal-bed methane-fueled power generation unit launched by PGNiG in Gilowice. http://en.pgnig. $\mathrm{pl} /$ news/-/news-list/id/coal-bed-methane-fueled-powergeneration-unit-launched-by-pgnig-in-gilowice/newsGroupId/1910852 [access: 1.03.2020].

Regulation of the Ministry of the Environment, 2013. Rozporzadzenie Ministra Środowiska $z$ dnia 29 stycznia 2013 r. w sprawie zagrożeń naturalnych $w$ zakładach górniczych. Dz.U. 2013 poz. 230.

Report, 1995-2018. Annual Report (for the years 1994-2018) on the state of basic natural and technical hazards in the hard coal mining industry. Gas hazard. Główny Instytut Górnictwa, Katowice.

State Mining Authority, 2019. Statystyki wypadków. Wyższy Urząd Górniczy, Katowice. http://www.wug.gov.pl/bhp/ statystyki_wypadkow [access: 1.06.2020].

Su S., Beath A., Guo H. \& Mallett C., 2005. An assessment of mine methane mitigation and utilisation technologies. Progress in Energy and Combustion Science, 31, 2, 123-170.

Swolkień J., 2020. Polish underground coal mines as point sources of methane emission to the atmosphere.
International Journal of Greenhouse Gas Control, 94, 102921. https://doi.org/10.1016/j.ijggc.2019.102921.

Szlązak N. (red.), 2015. Odmetanowanie górotworu w kopalniach węgla kamiennego. Wydawnictwa AGH, Kraków.

Szlązak N., Obracaj D. \& Głuch B., 2013. Estimation of microclimate condition in longwall excavations in hard coal mines. AGH Journal of Mining and Geoengineering, $37,1,117-128$.

Szlązak N., Obracaj D. \& Swolkień J., 2014. Methane drainage from roof strata using an overlying drainage gallery. International Journal of Coal Geology, 136, 99-115.

Szlązak N., Borowski M., Obracaj D., Swolkień J., Korzec M. \& Piergies K., 2017. Current ventilation problems in hard coal mines. Wydawnictwa AGH, Kraków.

Szlązak N., Obracaj D. \& Swolkień J., 2020. Enhancing Safety in the Polish High-Methane Coal mines: an Overview. Mining, Metallurgy \& Exploration, 37, 567-579.

Tauron - internal report [geological documentation, unpublished].

Tauron Brzeszcze mine website. https://www.tauron-wydobycie.pl/spolka/zg-brzeszcze/charakterystyka-zakladu [access: 1.02.2020].

Teper L. \& Sagan G., 1995. Geological history and mining seismicity in Upper Silesia (Poland). [in:] Rossmanith H.P. (ed.), Mechanics of Jointed and Faulted Rock, Balkema, Rotterdam, 939-943.

Thielemann T., Kroos B.M., Littke R. \& Welte D.H., 2001. Does coal mining induce methane emissions through the lithosphere/atmosphere boundary in the Ruhr Basin, Germany? Journal of Geochemical Exploration, 74, 219-231.

Trenczek S., 2016. Study of influence of tremors on combined hazards. Longwall mining operations in co-occurrence of natural hazards. A case study. Journal of Sustainable Mining, 15, 1, 36-47.

Turek M., 2007. Techniczna i organizacyjna restrukturyzacja kopalń węgla kamiennego. Główny Instytut Górnictwa, Katowice.

Warmuziński K., 2008. Harnessing methane emissions from coal mining. Process Safety and Environmental Protection, 86, 5, 315-320.

Wojsa B., 2019. Gilowice: metan z pokładów wegla trafi do sieci gazowej. https://dziennikzachodni.pl/gilowice-metan-z-pokladow-wegla-trafi-do-sieci-gazowej/ar/c114302541 [access: 1.03 .2020 ]

Yusuf R.O., Noor Z.Z., Abba A.H., Hassan M.A.A. \& Din M.F.M., 2012. Methane emission by sectors: a comprehensive review of emission sources and mitigation methods. Renewable and Sustainable Energy Reviews, $16,7,5059-5070$. 